Document downloaded from:

http://hdl.handle.net/10251/73481

This paper must be cited as:

González Nebauer, S.; Sánchez Perales, M.; Martinez, L.; Lluch Gomez, YP.; Renau Morata, B.; Molina Romero, RV. (2013). Differences in the photosynthetic response of three tomato cultivars to different salinity sources and their effect on vegetative growth parameters. Plant Physiology and Biochemistry. 63:61-69.

http://hdl.handle.net/10251/73481.

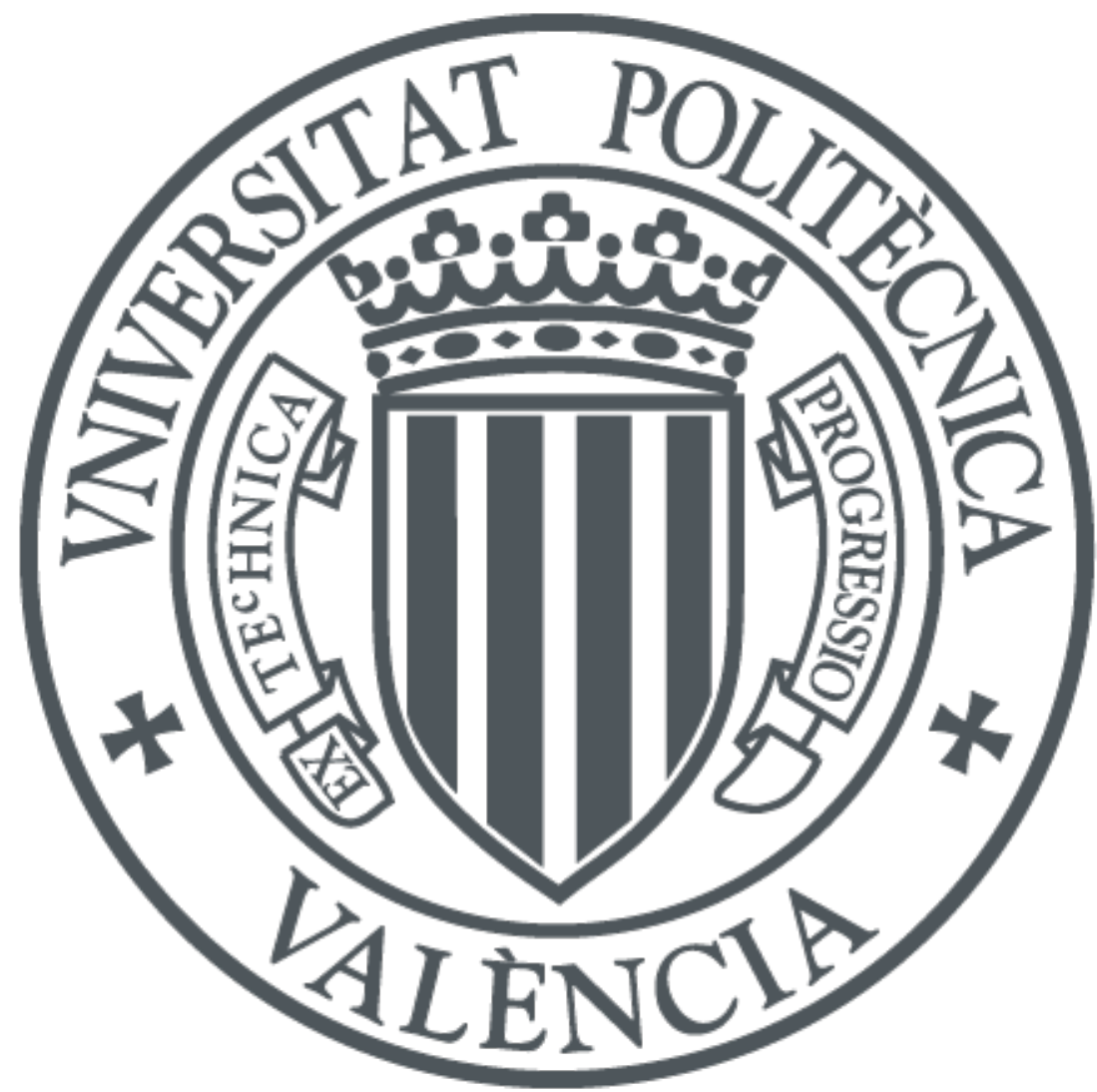

The final publication is available at

https://dx.doi.org/10.1016/j.plaphy.2012.11.006

Copyright Elsevier

Additional Information 


\section{Accepted Manuscript}

Differences in photosynthetic performance and its correlation with growth among tomato cultivars in response to different salts

Sergio G. Nebauer, Manuel Sánchez, Laura Martínez, Yolanda Lluch, Begoña Renau-Morata, Rosa Victoria Molina

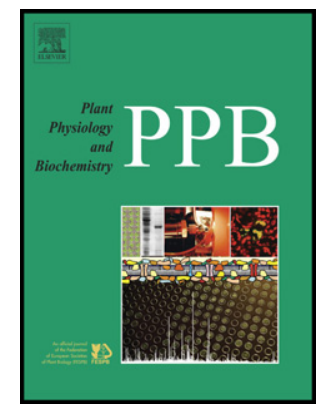

PII:

S0981-9428(12)00298-7

DOI: 10.1016/j.plaphy.2012.11.006

Reference: PLAPHY 3489

To appear in: Plant Physiology et Biochemistry

Received Date: 13 June 2012

Accepted Date: 7 November 2012

Please cite this article as: S.G. Nebauer, M. Sánchez, L. Martínez, Y. Lluch, B. Renau-Morata, R.V. Molina, Differences in photosynthetic performance and its correlation with growth among tomato cultivars in response to different salts, Plant Physiology et Biochemistry (2012), doi: 10.1016/ j.plaphy.2012.11.006.

This is a PDF file of an unedited manuscript that has been accepted for publication. As a service to our customers we are providing this early version of the manuscript. The manuscript will undergo copyediting, typesetting, and review of the resulting proof before it is published in its final form. Please note that during the production process errors may be discovered which could affect the content, and all legal disclaimers that apply to the journal pertain. 


\section{Highlights}

Photosynthesis and growth were more affected by $\mathrm{Na}_{2} \mathrm{SO}_{4}, \mathrm{MgCl}_{2}$ and $\mathrm{MgSO}_{4}$ than by $\mathrm{NaCl}$

Photosynthetic limitations under salt stress were cultivar-dependent

Salinity differentially affected photo-assimilate utilisation among tomato cultivars

Salt tolerance has been related to toxic ion exclusion and macroelement homeostasis 


\title{
Differences in photosynthetic performance and its correlation with growth among tomato cultivars in response to different salts.
}

Sergio G. Nebauer*, Manuel Sánchez, Laura Martínez, Yolanda Lluch, Begoña RenauMorata and Rosa Victoria Molina Departamento de Producción Vegetal, Universitat Politécnica de València, Camino de vera s.n., Valencia 46022, Spain

*Corresponding author. Tel.: +34 963877410; fax: +34 963877419

E-mail address: sergonne@bvg.upv.es

\begin{abstract}
Previous works into photosynthesis regulation under salt stress have focused on the effect of $\mathrm{NaCl}$, although other salts may significantly contribute to the toxicity of saline soils. In this paper, the effects of different salt sources $\left(\mathrm{NaCl}, \mathrm{Na}_{2} \mathrm{SO}_{4}, \mathrm{MgCl}_{2}\right.$ and $\left.\mathrm{MgSO}_{4}\right)$ on photosynthesis and vegetative growth in three tomato (Solanum lycopersicon L.) cultivars (Marmande RAF, Leader and Daniela) are presented. Differences were found in the net photosynthetic rate and vegetative growth among the studied cultivars and salinity treatments. Cultivar photosynthetic performance related not only to capability for toxic ion exclusion, but also to the maintenance of appropriate essential macronutrient concentrations in leaves. In addition, the role of metabolic and diffusion limitations in regulating photosynthesis varied depending on the studied genotypes. These data, along with variation in biomass and ion distribution in leaves and roots, show that distinct tomato cultivars can address salt tolerance differently, which should be considered when designing strategies to overcome plant sensitivity to salt stress.
\end{abstract}

Keywords: Solanum lycopersicon; salt stress; photosynthesis; photosynthetic limitations; ion content; biomass

\section{Introduction}

Tomato is an important horticultural crop in Spain, where more than 4 million tons were produced in 2008 [26]. This crop is cultivated in semi-arid regions in which soil and 
groundwater salinity are an increasing threat, affecting both tomato yield and quality [9]. Salinity is an acute problem in covered crops in SE Spain (30\% of the total tomato production surface area), where water quality is a major limiting factor. Increasing salinity of irrigation water diminishes crop productivity by reducing leaf growth and inducing leaf senescence, thus limiting the total photosynthetic capacity and the possibility of generating further harvestable biomass growth. Nevertheless, this response provides a defence mechanism against stress [23, 38].

Although many deleterious effects of salt on tomato plant growth and fruit production have been reported [9], in some cases, moderate salt stress can improve fruit quality [8, $21,27,31,33]$. Tomato plants irrigated with saline solutions transpire less water than tomatoes receiving fresh water [29, 30,35], and the use of saline irrigation water as part of the integrated approach described by Ragab [28] has been pointed out by ReinaSánchez et al. [29].

The ability to benefit from saline irrigation water, and the likelihood that agricultural production will expand into salt-affected marginal areas, will require a better understanding of the response of tomatoes to salt stress. Little is known about the primary keys of photosynthesis regulation in response to salt stress and their relation to intraspecific variation. The photosynthetic process in tomato can be negatively affected by salinity [30, 32, 37, 39]. However, these cited published works differ as far as their explanations of the cause of low photosynthesis rates and the influence of this reduction on diminished growth are concerned. Furthermore, the specific effect of other salts than $\mathrm{NaCl}$ present in saline soils and saline irrigation water has not yet been studied.

$\mathrm{Xu}$ et al. [39] found that the maximum photosynthesis rate increases in leaves (14-15\%) when the EC of the nutrient solution raises up to $4.0 \mathrm{dSm}^{-1}$, but a further increase of EC lowers this parameter. Schwarz et al. [32] reported that an increase of EC by up to 8.75 $\mathrm{dSm}^{-1}$ does not lower the leaf photosynthesis rate of tomato, but stated that a reduction in total plant growth is apparently caused by diminished leaf area, thereby reducing whole-plant photosynthesis, and not by changes in leaf photosynthesis per se. RomeroAranda et al. [30] showed that the leaf photosynthesis rate of tomato plants reduces proportionally as the $\mathrm{NaCl}$ concentration increases in the nutrient solution. They stated that the lower photosynthesis rate may result from reducing stomatal conductivity and stomatal density. Wu et al. [37] reported that the physiological response of tomato plants is cultivar- and growth-stage-specific, and that the maximum photosynthesis rate 
is affected by strong EC treatments $\left(8.4-14.3 \mathrm{dSm}^{-1}\right)$ and, in some cultivars, by intermediate EC treatments $\left(4.8-8.4 \mathrm{dSm}^{-1}\right)$.

Comparing the results obtained from different studies is difficult because of differences in experimental factors, such as cultivar, irradiance, $\mathrm{CO}_{2}$ concentration or nutrient solution composition. On the other hand, EC has been increased in several studies by intensifying the overall strength of nutrient solutions [32, 37, 39]. In other works however, $\mathrm{EC}$ was raised by supplying the nutrient solution with $\mathrm{NaCl}$ [30]. Although the presence of salt in the nutrient solution lowers the osmotic potential of the root environment, not all plant growth-related parameters are influenced by different salinity sources in the same way [1,21]. Furthermore, different cultivars have been used in the experiments conducted in various reported works, and the existence of a cultivarspecific physiological response has been observed [30, 37].

Although $\mathrm{NaCl}$ is the most common salt in saline soils, $\mathrm{Na}_{2} \mathrm{SO}_{4}$ and $\mathrm{MgSO}_{4}$ can also be found at high concentrations in these soils [15]. In addition, $\mathrm{MgCl}_{2}$ accumulates in extremely saline soils, where $\mathrm{Na}^{+}$is exchanged for $\mathrm{Mg}^{2+}$. No studies have examined the specific effects of salts other than $\mathrm{NaCl}$ on tomato growth and physiology, and the study of the specific response of these salts could prove interesting.

The relation between a reduced photosynthesis rate because of salt stress and diminished growth is not consistent among studies. Thus, in the work of RomeroAranda et al. [30], a reduction to $76 \%$ in the photosynthetic rate of the control did not lower plant dry weight in the Daniela cultivar, even though the leaf area also diminished. Further reduction in the photosynthesis rate to $40 \%$ of the control decreased dry weight to $79 \%$. No differences were found in the reduction of the photosynthesis rate (40-46\% of the control rate) in the Moneymaker cultivar when the nutrient solution was supplemented with $35 \mathrm{mM}$ or $70 \mathrm{mM} \mathrm{NaCl}$, but tomatoes irrigated at the lowest $\mathrm{NaCl}$ concentration showed greater dry weight. In the study of Schwarz et al. [32], increasing EC in the nutrient solution up to $8.75 \mathrm{dSm}^{-1}$ did not significantly affect leaf photosynthesis, and the diminished growth observed could be explained by the reduction in leaf area. Differences in cultivars could explain some of these varying results. However, the correlation found between photosynthesis and growth for specific cultivars has not been analysed, and this analysis is especially necessary when we consider the diverse cultivars that have been tested. Leaf growth inhibition under salt stress may be regulated by hormones or their precursors [25], and Albacete et al. [2] 
proposed a putative potassium-CK interaction involved in regulating leaf area in tomato. In this context, and to some extent, the leaf growth rate could be independent of carbohydrate availability. On the other hand, as Romero-Aranda et al. indicated [30], salt tolerance is addressed distinctly by different cultivars in tomato, and these diverse physiological responses may involve differences in energy costs, carbohydrate availability and the relation between photosynthesis and the growth rate.

In this paper, the specific effect of different sodium and magnesium salts on the photosynthesis rate and genotypic variability of the response was studied by emphasising the relation between response variability and stomatal and non-stomatal limitations, and the correlation between photosynthesis and growth. Our aim was to test the differences among the studied genotypes in tolerance to diverse common salts in saline soils and their relation with photosynthesis, growth parameters and ion distribution in leaves and roots. Diversity in the physiological response should be considered when planning strategies to improve tolerance to salt stress.

\section{Results}

\subsection{Influence of different sodium and magnesium salts on the $\mathrm{CO}_{2}$ fixation rate and} genotypic variability of the response

In all the genotypes, the addition of any salt to the culture medium resulted in a lowered photosynthetic rate $(P<0.05)$. The response was genotype-, salt type- and salt concentration-dependent (Fig. 1). With very few exceptions, the general trend was the higher the salt concentration, the greater the reduction. A drop in the photosynthetic rate was noticeable by day 4 of cultivation and, under some conditions, it became more pronounced with time. No tested genotype or saline condition recovered the initial photosynthetic rate.

At the end of the study period (day 12 of culture), no differences in the lowered photosynthetic rate were noted between genotypes when $\mathrm{NaCl}$ was added to the culture medium, no matter what the tested concentration. However, genotypic differences in the effect on the $\mathrm{CO}_{2}$ fixation rate were observed when any other salt $\left(\mathrm{Na}_{2} \mathrm{SO}_{4}, \mathrm{MgCl}_{2}\right.$ or 
$\mathrm{MgSO}_{4}$ ) was added (Fig. 1). Moreover, $\mathrm{NaCl}$ was the least toxic salt, especially at medium and high concentrations.

The lowest reduction in the $\mathrm{CO}_{2}$ fixation rate was observed in the presence of $\mathrm{Na}_{2} \mathrm{SO}_{4}$ in Daniela (Fig. 1). This reduction did not further increase with cultivation time $(P<0.05)$. It is noteworthy that the addition of $50 \mathrm{mM} \mathrm{Na}_{2} \mathrm{SO}_{4}$ only slightly lowered the photosynthetic rate $(9 \%)$ on day 12 of culture.

The addition of magnesium salts to the medium brought about a greater decrease in the photosynthetic rate than the addition of sodium salts in RAF and Daniela $(P<0.05)$. The response was markedly different in the medium with $50 \mathrm{mM} \mathrm{MgSO}_{4}$ at the end of the experiment when compared with Leader. In this medium, Leader gave a photosynthetic rate of $68 \%$ if compared to the control rate, while the rates were $27 \%$ and $17 \%$ of the control rate in Daniela and RAF, respectively (Fig. 1). RAF is generally more sensitive to intermediate or high concentrations of magnesium salt than the other genotypes. At $50 \mathrm{mM}$, magnesium salts diminished photosynthesis to less than $20 \%$ of the control level, and the $\mathrm{CO}_{2}$ fixation values dropped to $0-5 \%$ of the control value when the concentration was raised to $100 \mathrm{mM}$. However at low $\mathrm{MgSO}_{4}$ concentrations $(25 \mathrm{mM}), \mathrm{CO}_{2}$ fixation was similar to the control values at the end of the culture period (96\% of control).

At a high concentration, $\mathrm{MgCl}_{2}$ proved to be the most harmful salt for the photosynthetic process and crop survival. On day 4 of culture, the photosynthesis rate lowered to below $30 \%$ of the control rate in all three cultivars, and all the Daniela and RAF plants died before day 12 of culture.

When the effect of osmolarity on the photosynthesis rate was studied for the various salts, differences in the toxic effect of these salts among genotypes were observed (Fig. 2). At the same osmolarity, magnesium salts in the Daniela and RAF tomatoes provoked a greater drop in photosynthesis than sodium salts. However in Leader, hybrid sulphates lowered photosynthesis more than chlorides (Fig. 2).

\subsection{Diffusive and metabolic limitations to photosynthesis}

The increased osmolarity of the saline solution reduced stomatal conductivity (Fig. 3A). The rate of decline of conductivity with increasing osmolarity was lower in Daniela and 
RAF than in Leader. A high correlation between photosynthesis and stomatal conductance was observed in all the genotypes (Fig. 3B). The effect of osmolarity on stomatal conductance could partially explain the relationship between osmolarity and photosynthesis. However, the importance of stomatal factors in limiting $\mathrm{CO}_{2}$ fixation due to salinity led to differences among genotypes. In the Daniela tomatoes, substomatal $\mathrm{CO}_{2}$ availability correlated with the photosynthesis rate throughout the culture, which could explain $62 \%$ of observed variability (Fig. 4A). In the Leader hybrid, the drop in the photosynthetic rate observed when grown in media with salts could be attributed to lower substomatal $\mathrm{CO}_{2}$ until only day 4 of culture (Fig. 4B). For Leader, since this day, and for any of the days on which measurements were taken in RAF tomatoes, the decreased photosynthetic rate did not correlate with the reduced substomatal $\mathrm{CO}_{2}$ availability caused by stomatal closure. Indeed, at low photosynthetic values, the lower the photosynthetic rate, the greater substomatal $\mathrm{CO}_{2}$ availability (Fig. $4 \mathrm{C})$.

In order to estimate metabolic limitations to photosynthesis, photosynthetic parameters were obtained from the $A_{N} / C_{i}$ and $A_{N} / C_{c}$ response curves in the Leader and RAF cultivars on day 8 of culture in the medium with $50 \mathrm{mM} \mathrm{NaCl}$ (Table 2). No significant differences were observed in Ls between Leader and RAF under the control conditions $(P<0.05)$. Leaf Ls did not increase with salinity after day 8 in both cultivars. However, non-stomatal limitations ( $\mathrm{Lm}$ ) increased with salinity and were significantly higher in Leader $(P<0.05)$. In this cultivar, salt stress provoked a decrease in $\mathrm{V}_{\mathrm{c} \max }(46 \%$ of controls) and $\mathrm{J}_{\max }$ (64\% of controls), although the TPU rate remained unchanged (Table 2). No changes were observed in $\mathrm{J}_{\max }$ in RAF; however, $\mathrm{V}_{\mathrm{c} \text { max }}$ and TPU decreased (76\% and $61 \%$ of control, respectively). $\mathrm{NaCl}$ also enhanced mesophyll diffusion resistance in both cultivars.

Fluorescence measurements showed reduced maximum quantum efficiency of PSII when salt was added to the culture medium. This reduction did not exceed $20 \%$ of controls during the first 8 days of culture for any of the tested media or genotypes (data not shown). However after day 12 of culture, a phytotoxic effect was observed in some cases (Fig. 5). This effect was more pronounced in RAF, particularly in the media with magnesium salts, with values reaching maximum quantum efficiency of less than $40 \%$ of the control values in response to $100 \mathrm{mM} \mathrm{MgCl}_{2}$. 


\subsection{Correlations between photosynthesis rate and growth}

Plant growth diminished when the salt concentration increased (Table 3). The threshold was cultivar- and treatment-dependent. In all the tested genotypes, a positive correlation was found at the treatment level between the photosynthesis rate and the various studied growth parameters, such as dry weight of shoot and root, number of leaves and leaf area (Table 4): that is, the higher photosynthetic rates for a treatment in a certain genotype were associated with better plant growth. However, differences among genotypes were found; the relation between photosynthesis and growth was greater in RAF and lower in Daniela.

However at the genotypic level, the analysis of the correlations between photosynthesis and growth showed that the genotypes with a less reduced photosynthetic rate were not always those genotypes with less diminished growth (Fig. 1 and Table 3). In the media with sodium salts (50-100 mM NaCl or $50-100 \mathrm{mM} \mathrm{Na}_{2} \mathrm{SO}_{4}$ ), RAF showed a more reduced photosynthesis rate than, or similar to, the other genotypes, but growth (shoot dry weight) was similar to, or greater than, the control. On the other hand in the media with magnesium salts, Daniela exhibited similar or greater growth than the other genotypes if compared to the control, although the reduction in the photosynthesis rate was similar or greater. This result was observed for the media with $25-50 \mathrm{mM} \mathrm{MgSO}_{4}$.

The correlation between shoot dry weight and root dry weight at the treatment level was higher than 0.9 for all the genotypes $(\mathrm{r}=0.93 ; P<0.01$ in Daniela and the hybrid Leader, and $\mathrm{r}=0.95 ; P<0.01$ in RAF), but the reduction in shoot growth due to the presence of salts in the medium was usually less than the decrease in root growth. Thus, the ratio between measured shoot growth and root growth in relation to control values usually produced values of over 1 (Table 5). Genotypic differences were found for this parameter. The Leader variety always showed the smallest ratio between shoot growth and root growth, and it was the only genotype that displayed a greater reduction in shoot growth than in root growth in some media (specifically, those media with high sodium concentrations). Furthermore, the shoot growth/root growth ratio was lower in the media with sodium salts than in those with magnesium salts for all the genotypes. 


\subsection{Genotypic differences for influence of salinity on ion content}

In order to study the existence of genotypic differences that explain variation in ion content in plant tissues due to the culture of plants in saline media, the calcium, potassium, magnesium, sodium, chloride, phosphate and sulphate content in the leaves and roots of the Daniela and RAF tomato plants was measured. These varieties gave the lowest and highest correlations between photosynthesis and growth, respectively.

When the RAF tomato was grown in saline media, the $\mathrm{Ca}^{2+}$ and $\mathrm{K}^{+}$content in leaves significantly lowered. These concentrations decreased to around $30 \%$ of the control concentrations in the media with high salt concentrations (Table 6). Additionally, the phosphorus concentration in leaves was affected by salinity in the RAF tomato and reached values of $30 \%$ of the control at high $\mathrm{MgCl}_{2}$ concentrations.

However in the Daniela tomato, no such marked change was noted in the $\mathrm{K}^{+}$and $\mathrm{Ca}^{2+}$ concentration in leaves (Table 6). These cations were always found at concentrations above $70-80 \%$ of controls. Furthermore, the phosphorus concentration in leaves did not significantly differ from controls.

$\mathrm{Na}^{+}$and $\mathrm{Mg}^{2+}$ leaf content raised linearly $(\mathrm{r}>0.7)$ to the concentration of the media (Table 6). However, the accumulation rate was higher in RAF than in Daniela. The same behaviour was observed for $\mathrm{Cl}^{-}$in $\mathrm{RAF}$. Nevertheless, $\mathrm{Cl}^{-}$content in Daniela remained at around $1.3 \mathrm{mmol} \mathrm{g}^{-1} \mathrm{DW}$ in media with up to $100 \mathrm{mM} \mathrm{Cl}^{-}$. Only at the highest concentration ( $\left.200 \mathrm{mM} \mathrm{Cl}^{-}\right)$did this ion significantly accumulate in leaves. Sulphate content in leaves correlated positively with the concentration in the media in Daniela $(r=0.92)$ and RAF $(r=0.98)$, although the accumulation rate was much higher in RAF (Table 6).

Unlike leaves, we did not find significant differences among genotypes in terms of reduced $\mathrm{K}^{+}$and $\mathrm{Ca}^{2+}$ content in roots when tomato plants were grown in saline media with excess $\mathrm{Na}^{+}$or $\mathrm{Mg}^{2+}$ (data not shown). Furthermore in most media, no differences among genotypes were observed for reduced phosphorus content in roots. This reduction was only higher in the RAF tomatoes when grown in a media with a very high $\mathrm{MgSO}_{4}$ concentration.

\section{Discussion}


Very little is known about photosynthetic regulation in response to salt stress and its variability in relation with genotypic variation in tomato [30]. Indeed most studies have analysed the presence of $\mathrm{NaCl}$ or increased overall strength of the nutrient solution. As far as we know, no studies have examined the specific effects of other salts that can also be found at high concentrations in saline soils or irrigation water. In this work, we identify genotypic variation for tolerance to different salts at high concentrations in saline soils. Moreover, we find that this variability involves differences in the influence of stomatal and non-stomatal effects on reduced photosynthesis rates, the relationship between photosynthesis and growth parameters, and ion content.

No differences were found in the decrease in photosynthetic rate among the studied genotypes when $\mathrm{NaCl}$ was added to the culture medium, regardless of the tested concentration; thus, $\mathrm{NaCl}$ is the least toxic salt for tomatoes. However, genotypic differences were observed in the photosynthesis rate when sodium sulphate and magnesium sulphate, both of which are found at high concentrations in saline soils, or magnesium chloride, which accumulates in soils at an extremely high salinity, were added to the medium.

RAF is generally more sensitive to intermediate or high concentrations of salts than the other genotypes, and the differences were more pronounced in the media with magnesium salts. In the Daniela cultivar, the decrease in photosynthetic rate, which lowered due to medium-high sodium sulphate concentrations, was lower than in the other two genotypes. However, magnesium salts lowered photosynthesis to a greater extent in Daniela and RAF than in Leader, which generally presented a higher photosynthetic rate after adding such salts to the medium. Differences among genotypes in the effects of EC of hydroponic nutrient solution on the photosynthesis rate have been described by diverse authors $[30,37]$.

In relation to the reasons for lowering the photosynthesis rate with the increasing salt concentration in the media, the results we obtain reveal that exposure of tomato to low, moderate or high salinity can affect the photosynthesis rate through not only osmotic effects. Ion-specific toxicity effects were also observed, and genotypic variation in response to diverse salt sources should be taken into account.

As expected, a strong correlation between photosynthesis and stomatal conductance was observed in all the genotypes when taking into account the importance of the $\mathrm{CO}_{2}$ 
concentration in regulating stomatal opening. However, differences among genotypes appeared in terms of the importance of stomatal factors in limiting the photosynthesis rate due to saline treatments. In Daniela, substomatal $\mathrm{CO}_{2}$ availability could explain most observed variability, and the relation was maintained throughout the culture period. However with RAF and the hybrid Leader, from day 8 of culture onward, the lowered photosynthesis rate did not correlate with diminished substomatal $\mathrm{CO}_{2}$ availability due to stomatal closure. Our photosynthetic limitations estimates based on $\mathrm{A}_{\mathrm{N}}-\mathrm{Ci}$ and $\mathrm{A}_{\mathrm{N}}-\mathrm{C}_{\mathrm{c}}$ analyses suggest higher metabolic limitations with salt stress in the RAF and Leader tomatoes. Moreover, stomatal limitations remain unaffected. Thus, even if stomatal closure occurs with increasing salinity, the drop in $\mathrm{CO}_{2}$ fixation due to metabolic causes will maintain a level of substomatal $\mathrm{CO}_{2}$ that will not limit $\mathrm{CO}_{2}$ fixation to a greater extent than in controls. Nevertheless, patchy stomatal closure [6] and changes in cuticular [5] and $g_{m}$ [7] must be considered. There is an increasing body of evidence indicating that $g_{m}$ decreases in response to drought and salinity $[11,13,20]$. Our results confirm the limitations in mesophyll resistance in the two genotypes analysed under salinity stress conditions. Thus, we conclude that stomatal closure and increased mesophyll resistance initially limit photosynthesis due to $\mathrm{CO}_{2}$ availability, but subsequently, this low $\mathrm{CO}_{2}$ level can lead to leaf metabolism changes, as suggested by other authors [14]. The mechanisms that down-regulate $g_{m}$ under salinity are still unknown, although they may involve regulation of proteins like aquaporins or carbonic anhydrase. Regarding metabolic limitations, we observed variability in the two analysed genotypes' response. A reduction in active Rubisco was noted in the hybrid Leader, as indicated by the decreased $V_{c \max }$, as well as limited RuBP regeneration due to an inadequate ATP or NADPH supply of enzymatic activities, as indicated by the reduction of $\mathrm{J}_{\mathrm{max}}$. Nevertheless, the TPU rate lowered for RAF, and the maximum quantum efficiency of PSII significantly diminished.

$\mathrm{Xu}$ et al. [39] and Romero-Aranda et al. [30] reported that the photosynthesis rate is more affected by a limited $\mathrm{CO}_{2}$ supply than by biochemical processes. Romero-Aranda et al. [30] ruled out the reduction of photochemical activity as the cause of a lower photosynthesis rate because of the strong correlation between $g_{s}$ and $A_{N}$. However, this relation was maintained, even though non-stomatal factors lowered the photosynthesis rate due to the importance of $\mathrm{CO}_{2}$ concentration in regulating stomatal opening. $\mathrm{Xu}$ et al. [39] found that the photosynthetic depression caused by a high EC can be attributed more to $\mathrm{g}_{\mathrm{s}}$ reduction than to $\mathrm{g}_{\mathrm{m}}$ depression, suggesting that $\mathrm{CO}_{2}$ diffusion through 
stomata is affected more than biochemical processes. However, biochemical constraints were not excluded. Wu and Kubota [37] found that the effects of EC treatments on leaf photosynthetic light response curves are cultivar-specific. However, the relative importance of stomatal and non-stomatal constraints to the photosynthetic process was not analysed. Thus we may conclude that, in addition to the differences in terms of increased metabolic and diffusion limitations due to the effect of salinity among cultivars, there were differences in the affected metabolic processes leading to changes in photosynthetic capacity. This should be considered when designing strategies to overcome sensitivity to salt stress.

According to Adams [1] and Sonneveld [34], growth reduction is expected for tomato within the $6 \%$ to $10 \%$ range for each $1 \mathrm{dS} \mathrm{m}^{-1}$ increase in nutrient solution EC, depending on cultivar and nutrient composition. Our results confirm these findings, and a strong correlation was found at the treatment level between the photosynthesis rate and the diverse studied growth parameters in all the tested genotypes. For a given genotype, higher photosynthesis rates correlated with greater plant growth. However, differences were noted among genotypes. The relationship between photosynthesis and growth was stronger in RAF and weaker in Daniela. Furthermore for some treatments, the genotypes with slighter photosynthesis rate reductions were not the same genotypes with least reduced growth. Differences in the correlation between photosynthesis and growth have been found among genotypes in other studies. Balibrea et al. [3] found that photosynthesis positively correlates with plant growth in cv. Pera, but not cv. Volgogradskij, and they observed a different behaviour in both genotypes in terms of the distribution and use of photo-assimilates, which could explain their differing salt tolerances.

The photo-assimilates produced under salt stress are used to support crucial, mutually exclusive processes, such as growth, maintenance and osmotic adjustment. Competition between different physiological processes and sink organs for limited carbon supplies under salinity significantly affects overall plant growth and crop yield [3, 10, 24]. We found slight differences for the relation between photosynthesis and growth among genotypes. Saline-cultivated Daniela and RAF tomato plants respectively showed the weakest and strongest correlation between photosynthesis and growth. In addition, the analysis of ion content in leaves and roots produced differences that could at least 
partially explain differences in the use of photo-assimilates. We found that the foliar $\mathrm{Na}^{+}, \mathrm{Cl}^{-}, \mathrm{SO}_{4}{ }^{2-}$ or $\mathrm{Mg}^{2+}$ content in Daniela is lower than in RAF leaves. The only exception found is the medium with $100 \mathrm{mM} \mathrm{MgCl}_{2}$. These results suggest that the salt tolerance mechanism based on $\mathrm{Na}^{+}, \mathrm{Mg}^{2+}, \mathrm{SO}_{4}{ }^{2-}$ and/or $\mathrm{Cl}^{-}$exclusion from leaf blades is more important in Daniela than in RAF under all the tested salt stress conditions. Furthermore, the reduction in absorption of calcium, potassium and phosphorus was weaker in Daniela, whose leaves showed a stronger correlation between $\mathrm{K}^{+}$and $\mathrm{Na}^{+}$ than RAF. The $\mathrm{K}^{+}$concentration in the cytoplasm in relation to that of $\mathrm{Na}^{+}$may be a contributing factor to salinity tolerance $[22,25]$. On the other hand, the fact that RAF leaves accumulate more $\mathrm{Na}^{+}$than Daniela leaves may indicate that the RAF cultivar is less able to regulate $\mathrm{Na}^{+}$accumulation and this, in turn, may be responsible for its higher salt sensibility. Our results support the finding of Romero-Aranda et al. [30], who showed how different cultivars address salt tolerance differently.

The identification of cultivars that show differences in the photosynthetic response, exclusion of ions from leaf blades and photo-assimilates use under salt stress conditions is a necessary starting point to study the key regulatory steps in response to salt stress and the involvement of genes related to salt stress tolerance.

\section{Materials and methods}

\subsection{Plant material}

Daniela, Leader and Marmande RAF tomato cultivars (Solanum lycopersicum L.) were used in this study. Leader seeds were kindly provided by Isi Sementi (Italy). Daniela and Marmande RAF are cultivars of raw tomatoes grown in SE Spain, where the salinity problem is especially acute. Leader F1 is currently used by the food industry in Italy, where availability of good quality irrigation water is also limited in southern parts of the country.

Seeds were germinated on a moistened mixture of peat moss and sand in growth chambers $\left(25 / 20^{\circ} \mathrm{C}, 16 / 8 \mathrm{~h}\right.$ light/dark photoperiod). Susbtrate was carefully removed from the roots of 3-week old uniform plantlets, which had three leaves, and were 
transferred to 1-litre plastic pots containing half-strength Hoagland solution [17]. Hydroponic cultures were regularly aerated and kept in a greenhouse.

\subsection{Salt stress assays}

After 1 week in nutrient solution, four different salts were added to the medium $(\mathrm{NaCl}$, $\mathrm{Na}_{2} \mathrm{SO}_{4}, \mathrm{MgCl}_{2}$ and $\left.\mathrm{MgSO}_{4}\right)$ at three different concentrations (25, 50 and $100 \mathrm{mM}$ ). Maximum light (PAR) in the greenhouse was approximately $700 \mu \mathrm{mol} \mathrm{m} \mathrm{m}^{-1}$, and temperature ranged between $20^{\circ} \mathrm{C}$ (minimum) and $30^{\circ} \mathrm{C}$ (maximum). Osmolarity, electrical conductivity (EC) and osmotic potential of the solutions are provided in Table 1. Solutions were renewed every 4 days. Salinity treatments lasted 12 days.

\subsection{Photosynthesis measurements}

Instantaneous determinations of net $\mathrm{CO}_{2}$ assimilation $\left(A_{\mathrm{N}}\right)$, stomatal conductance $\left(g_{\mathrm{s}}\right)$, transpiration (E) and the substomatal $\mathrm{CO}_{2}$ concentration $\left(C_{\mathrm{i}}\right)$ were carried out under conditions of saturating light $\left(1200 \mu \mathrm{mol} \mathrm{m} \mathrm{m}^{-2} \mathrm{~s}^{-1}\right)$, a vapour pressure difference (vpd) between 1 and $2 \mathrm{kPa}$ and at 400 ppm CO CO $_{2}$ with a LI-6400 (LI-COR, Nebraska, USA). Measurements were taken from 9 am to12 am (local time). Maximum photochemical efficiency $\left(F_{\mathrm{v}} / F_{\mathrm{m}}\right)$ on dark-adapted leaves was measured using a portable pulse amplitude modulation fluorometer (MINI PAM, Walz, Effeltrich, Germany). One measurement per plant (gas exchange and fluorescence) was taken on the third or fourth leaf from the shoot apex. For each genotype, 12 plants were measured for all 13 saline treatments (4 different salts x 3 different concentrations, plus 1 control) on days 4, 8 and 12 of culture.

The maximum rate of Rubisco-mediated carboxylation $\left(V_{\mathrm{c} \max }\right)$, mesophyll conductance $\left(\mathrm{g}_{\mathrm{m}}\right)$ and the electron transport $\left(\mathrm{J}_{\max }\right)$ maximum rate were estimated in the attached leaves from the $A_{\mathrm{N}} / C_{\mathrm{c}}$ curves based on the equations of Farquhar et al. [12] and using the modifications of Harley and Sharkey [16]. The rate of triose phosphate utilisation (TPU) was estimated from the $\mathrm{A}_{\mathrm{N}} / \mathrm{Ci}$ curves. Temperature was maintained at $25^{\circ} \mathrm{C}$, irradiance was kept at $1200 \mu \mathrm{mol}$ photon $\mathrm{m}^{-2} \mathrm{~s}^{-1}$, vpd was between 1 and $2 \mathrm{kPa}$, while the ambient $\mathrm{CO}_{2}$ concentration $\left(C_{\mathrm{a}}\right)$ in the cuvette was controlled with a $\mathrm{CO}_{2}$ mixer 
across the series 400, 300, 200, 100, 50, 400, 600, 800, 1000, 1200, 1400, 1600, 1800 and $2000 \mathrm{ppm}$. Measurements were recorded after equilibration to a steady state, and $\mathrm{CO}_{2}$ leakage was determined at each $C_{\mathrm{a}}$ value by placing a dead leaf on the cuvette [19]. Five independent $A_{\mathrm{N}} / C_{\mathrm{c}}$ curves were produced per treatment. Stomatal $\left(\mathrm{L}_{\mathrm{s}}\right)$ and nonstomatal $\left(\mathrm{L}_{\mathrm{m}}\right)$ limitations to $\mathrm{A}_{\mathrm{N}}$ were estimated from the relationships between $\mathrm{A}_{\mathrm{N}}$ and $\mathrm{C}_{\mathrm{i}}$, as described by Lawlor [18].

\subsection{Growth parameter analysis}

Shoot and root fresh weights, leaf area and number of leaves were measured after 12 days of experiments. For each genotype, 12 plants were measured for all 13 saline treatments (4 different salts x 3 different concentrations, plus 1 control). The dry weights of shoot and root were measured after drying at $60^{\circ} \mathrm{C}$ for $48 \mathrm{~h}$.

\subsection{Mineral composition}

For all 13 saline treatments, sodium, calcium, magnesium, potassium and phosphate content ( $\mathrm{mmol} \mathrm{g}^{-1}$ of dry weight) was determined in leaves and roots on day 8 with an ICP-AES (Thermo Scientific, USA). Chloride content ( $\mathrm{mmol} \mathrm{g}^{-1}$ of dry weight) was quantified with a chloride analyser (Jenway, USA). Sulphate was quantified by capillary electrophoresis, as described by Blake et al. [4]. For each genotype, 12 plants of each treatment were randomly distributed into three groups of four plants. Thus, three independent extracts, corresponding to each group, were obtained for each treatment. Two mature leaves $\left(3^{\text {th }}\right.$ and $4^{\text {th }}$ from the apex) per plant were sampled and pooled together for each extract.

\subsection{Statistical analysis}

Treatment comparisons were analysed using ANOVA (Statgraphics Plus 5.1 for Windows, Statistical Graphics Corp.). Mean separations were performed with the LSD multiple range test. Regression analysis was used to evaluate the relations between parameters. 


\section{Acknowledgements}

This research has been supported by the Spanish Ministry of Education and Science (GEN2006-27772-C2-2-E/VEG). We thank Dr. Jaume Flexas and Dr. Miquel Rivas for their assistance with photosynthetic parameters modelling, and Dr. A. Calatayud for her assistance in the mineral content determinations. We thank Helen Warburton for revising the language in the manuscript.

\section{References}

[1] P. Adams, Effects of increasing the salinity of the nutrient solution with major nutrients or sodium chloride on the field, quality and composition of tomatoes grown in rockwool, J. Hortic. Sci. 66 (1991) 201-207.

[2] A. Albacete , C. Martinez-Andujar, M.E. Ghanem, M. Acosta, J. Sanchez-Bravo, M.J. Asins, J. Cuartero, S. Lutts, I.C. Dodd, F. Perez-Alfocea, Rootstock-mediated changes in xylem ionic and hormonal status are correlated with delayed leaf senescence, and increased leaf area and crop productivity in salinized tomato, Plant Cell Envir. 32 (2009) 928-938.

[3] M.E. Balibrea, J. Dell'Amico, M.C. Bolarin, F. Pérez-Alfocea, Carbon partitioning and sucrose metabolism in tomato plants growing under salinity, Physiol. Plant. 110 (2000) 503-511.

[4] M.M.A. Blake-Kalff, K.R. Harrison, M.J. Hakesford, F.J. Zhao, S.P. McGrath, Distribution of sulphur within oilseed rape leaves in response to sulphur deficiency during vegetative growth, Plant Physiol. 118 (1998) 1337-1344.

[5] J. S. Boyer, S.C. Wong, G.D. Farquhuar, $\mathrm{CO}_{2}$ and water vapour exchange across leaf cuticle (epidermis) at various water potentials, Plant Physiol. 114 (1997) 185191.

[6] T.N. Buckley, G.D. Farquhuar, K.A. Mott, Qualitative effects of patchy stomatal conductance distribution features on gas-exchange calculations, Plant Cell Envir. 20 (1997) 867-880. 
[7] M. Centritto, F. Loreto, K. Chartzoulakis, The use of low $\left[\mathrm{CO}_{2}\right]$ to estimate diffusional and non-diffusional limitations of photosynthetic capacity of saltstressed olive samplings, Plant Cell Envir. 26 (2003) 585-594.

[8] P.S. Cornish, Use of high electrical conductivity of nutrient solution to improve quality of salad tomatoes (Lycopersicon esculentum) grown in hydroponic culture, Austr. J. Exp. Agric. 32 (1992) 513-520.

[9] J. Cuartero, R. Fernandez-Munoz, Tomato and salinity, Sci. Hortic. 78 (1999) 83125.

[10] J. Daie, The activist scientist, Science 272 (1996) 1081-1081.

[11] S. Delfine, A. Alvino, M. Zacchini, F. Loreto, Consequences of salt stress on conductance to $\mathrm{CO}_{2}$ diffusion, Rubisco characteristics and anatomy of spinach leaves, Austr. J. Plant Physiol. 25 (1998) 395-402.

[12] G.D. Farquhar, S. von Caemmerer, J.A. Berry, A biochemical model of photosynthetic $\mathrm{CO}_{2}$ assimilation in leaves of C3 species, Planta 149 (1980) 78-90.

[13] J. Flexas, J. Bota, J.M. Escalona, B. Sampol, H. Medrano, Effects of drought on photosynthesis in grapevines under field conditions: an evaluation of stomatal and mesophyll limitations, Funct. Plant Biol. 29 (2002) 461-471.

[14] J. Flexas, J. Bota, F. Loreto, G. Cornic, T.D. Sharkey, Diffusive and metabolic limitations to photosynthesis under drought and salinity in C3 plants, Plant Biol. 6 (2004) 269-279.

[15] T.J. Flowers, P.F. Troke, A.R. Yeo, The mechanism of salt tolerance in halophytes, Ann. Rev. Plant Physiol. 28 (1977) 89-121.

[16] P.C. Harley, T.D. Sharkey, An improved model of $\mathrm{C} 3$ photosynthesis at high $\mathrm{CO}_{2}$. Reversed $\mathrm{O}_{2}$ sensitivity explained by lack of glycerate reentry into the chloroplast, Photosynth. Res. 27 (1991) 169-178.

[17] D.R. Hoagland, D.I. Arnon, The water culture method for growing plant without soil, Calif. Agric. Exp. Station 347 (1950) 
[18] D.W. Lawlor, Limitation to photosynthesis in water-stressed leaves: stomata vs metabolism and the role of ATP, Ann. Bot. 89 (2002) 871-885.

[19] S.P. Long, C.J. Bernacchi, Gas exchange measurements, what can they tell us about the underlying limitations to photosynthesis? Procedures and sources of error, J. Exp. Bot. 54 (2003) 2393-2401.

[20] F. Loreto, M. Centritto, K. Chartzoulakis, Photosynthetic limitations in olive cultivars with different sensitivity to salt stress, Plant Cell Envir. 26 (2003) 595601.

[21] F. Montesano, M.W. van Iersel, Calcium can prevent toxic effects of $\mathrm{Na}^{+}$on tomato leaf photosynthesis but does not restore growth, J. Amer. Soc. Hortic. Sci. 132 (2007) 310-318.

[22] C. Mota-Cadenas, C. Alcaraz-López, M.C. Martínez-Ballesta, M. Carvajal, How salinity affects $\mathrm{CO}_{2}$ fixation by horticultural crops, HortSci. 45 (2010) 1798-1803.

[23] R. Munns, Comparative physiology of salt and water stress, Plant Cell Envir. 25 (2002) 239-250.

[24] R. Munns, A. Termaat, Whole-plant responses to salinity, Austr. J. Plant Physiol. 13 (1986) 143-160.

[25] R. Munns, M. Tester, Mechanisms of salinity tolerance, Ann. Rev. Plant Biol. 59 (2008) 651-681.

[26] National Agricultural Statistics, Ministerio de Agricultura, Pesca y Alimentación, Spain (2009)

[27] Z. Plaut, Irrigation with low-quality water: Effects on productivity, fruit quality and physiological processes of vegetable crops, 2nd Int. Symp. Irrig.Hortic. Crops 449 (1997) 591-597.

[28] R. Ragab, An integrated modelling approach for irrigation water management using saline and non-saline water: The SALTMED model, Proc. Int. Symp. Tech. Control Salinity Hortic. Prod. 573 (2002) 129-138. 
[29] A. Reina-Sanchez, R. Romero-Aranda, J. Cuartero, Plant water uptake and water use efficiency of greenhouse tomato cultivars irrigated with saline water, Agric. Water Manag. 78 (2005) 54-66.

[30] R. Romero-Aranda, T. Soria, J. Cuartero, Tomato plant-water uptake and plantwater relationships under saline growth conditions, Plant Sci. 160 (2001) 265-272.

[31] Y. Sakamoto, S. Watanabe, T. Nakashima, K. Okano, Effects of salinity at two ripening stages on the fruit quality of single-truss tomato grown in hydroponics, J. Hortic. Sci. Biotech.74 (1999) 690-693.

[32] D. Schwarz, H.P. Klaring, M.W. van Iersel, K.T. Ingram, Growth and photosynthetic response of tomato to nutrient solution concentration at two light levels, J. Amer. Soc. Hortic. Sci. 127 (2002) 984-990.

[33] F. Serio, L. de Gara, S. Caretto, L. Leo, P. Santamaria, Influence of an increased $\mathrm{NaCl}$ concentration on yield and quality of cherry tomato grown in posidonia (Posidonia oceanica (L) Delile), J. Sci. Food Agric. 84 (2004) 1885-1890.

[34] C. Sonneveld, The salt tolerance of greenhouse crops. Neth. J. Agric. Sci. 36 (1988) 63-73.

[35] T. Soria, J. Cuartero, Tomato fruit yield and water consumption with salty water irrigation, Int. Symp. Water Quality Quantity Greenhouse Hortic. 458 (1998) 215219.

[37] M. Wu, C. Kubota, Effects of electrical conductivity of hydroponic nutrient solution on leaf gas exchange of five greenhouse tomato cultivars, HortTech. 18 (2008) 271-277.

[38] A.R. Yeo, Salinity, in: A.R. Yeo, T.J. Flowers (Eds), Plant solute transport, Oxford, 2007 pp. 340-365.

[39] H.L. Xu, L. Gauthier, A. Gosselin, Effects of fertigation management on growth and photosynthesis of tomato plants grown in peat, rockwool and NFT, Sci. Hort. 63 (1995) 11-20. 


\section{Legends for Figures}

Fig. 1. Reduction (\% of control values) in the net photosynthetic fixation rate caused by treating Daniela (white bars), Leader (grey bars) and RAF (black bars) tomato cultivars with different concentrations of $\mathrm{NaCl}, \mathrm{Na}_{2} \mathrm{SO}_{4}, \mathrm{MgCl}_{2}$ and $\mathrm{MgSO}_{4}$. Photosynthesis was measured after 4, 8 and 12 days of salinity treatments. Each value is the mean $( \pm \mathrm{SE})$ of 12 measurements in 12 different plants. Different letters indicate significant differences among cultivars $(P<0.05)$.

Fig. 2. The relation between the photosynthesis rate (\% controls) and osmolarity in the Daniela (A), Leader (B) and RAF (C) tomato cultivars under different salinity treatments: $\mathrm{NaCl}$ (white triangles), $\mathrm{Na}_{2} \mathrm{SO}_{4}$ (white squares), $\mathrm{MgCl}_{2}$ (black triangles) and $\mathrm{MgSO}_{4}$ (black squares). Each value is the mean of 12 measurements in 12 different plants $( \pm \mathrm{SE})$. Linear regressions are presented in the Figures (and ordered by a decreasing slope).

Fig. 3. The relation between $(A)$ stomatal conductance $\left(g_{s}\right)$ and osmolarity and $(B)$ the net $\mathrm{CO}_{2}$ fixation rate $\left(\mathrm{A}_{\mathrm{N}}\right)$ and stomatal conductance in Daniela (white circles), Leader (grey circles) and RAF (black circles) tomato cultivars. The exponential and logarithmic regressions are presented in the Figures.

Fig. 4. The relation between the net $\mathrm{CO}_{2}$ fixation rate $\left(\mathrm{A}_{\mathrm{N}}\right)$ and the substomatal $\mathrm{CO}_{2}$ concentration $\left(\mathrm{C}_{\mathrm{i}}\right)$ in Daniela tomato $(\mathrm{A})$, in Leader until day 4 of the experiment $(\mathrm{B})$, and at low photosynthetic rates in the RAF and Leader cultivars (C). The linear 
regressions are presented in the Figures. Each value is the mean of 12 measurements in 12 different plants $( \pm \mathrm{SE})$.

Fig. 5. Effect of salinity (\% of controls) on the maximum quantum efficiency of the PSII $\left(F_{v} / F_{m}\right)$ in the Daniela $(A)$, Leader $(B)$ and RAF $(C)$ tomato cultivars. Each value is the mean of 12 determinations in 12 different plants after 12 days of salinity treatments: 25 (white bars), 50 (grey bars) and $100 \mathrm{mM}$ (black bars) of $\mathrm{NaCl}, \mathrm{Na}_{2} \mathrm{SO}_{4}, \mathrm{MgCl}_{2}$ and $\mathrm{MgSO}_{4}$. Within each salt, different letters indicate significant differences $(P<0.05)$. 
Table 1

The salt concentration, osmolarity, electric conductivity (EC) and osmotic potential $\left(\Psi_{\Pi}\right)$ of the nutrient solutions used in the salt stress assays. Salts are added to the half-strength Hoagland growth medium.

\begin{tabular}{|c|c|c|c|c|}
\hline Salt & $\begin{array}{l}\text { Concentration } \\
\qquad(\mathrm{mM})\end{array}$ & $\begin{array}{l}\text { Osmolarity } \\
\text { (osmol) }\end{array}$ & 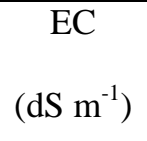 & $\begin{array}{c}\Psi_{\Pi} \\
(\mathrm{MPa})\end{array}$ \\
\hline- & - & - & 1.1 & -0.039 \\
\hline \multirow[t]{3}{*}{$\mathrm{NaCl}$} & 25 & 50 & 3.6 & -0.147 \\
\hline & 50 & 100 & 5.9 & -0.255 \\
\hline & 100 & 200 & 11.0 & -0.470 \\
\hline \multirow[t]{3}{*}{$\mathrm{Na}_{2} \mathrm{SO}_{4}$} & 25 & 75 & 5.2 & -0.185 \\
\hline & 50 & 150 & 8.6 & -0.318 \\
\hline & 100 & 300 & 15.8 & -0.573 \\
\hline \multirow[t]{3}{*}{$\mathrm{MgCl}_{2}$} & 25 & 75 & 5.8 & -0.197 \\
\hline & 50 & & 9.5 & -0.347 \\
\hline & 100 & 300 & 17.7 & -0.648 \\
\hline \multirow[t]{3}{*}{$\mathrm{MgSO}_{4}$} & 25 & 50 & 3.9 & -0.118 \\
\hline & 50 & 100 & 6.1 & -0.188 \\
\hline & 10 & 200 & 9.6 & -0.315 \\
\hline
\end{tabular}


Table 2

Effect of salt stress $(50 \mathrm{mM} \mathrm{NaCl})$ on stomatal $\left(\mathrm{L}_{\mathrm{s}} ; \%\right)$ and non-stomatal $\left(\mathrm{L}_{\mathrm{m}} ; \%\right)$ limitations to photosynthesis, stomatal conductance $\left(\mathrm{g}_{\mathrm{s}} ; \mathrm{mol} \mathrm{m} \mathrm{m}^{-2} \mathrm{~s}^{-1}\right)$, mesophyll conductance $\left(\mathrm{g}_{\mathrm{m}} ; \mathrm{mol} \mathrm{m} \mathrm{m}^{-2} \mathrm{~s}^{-1}\right)$,

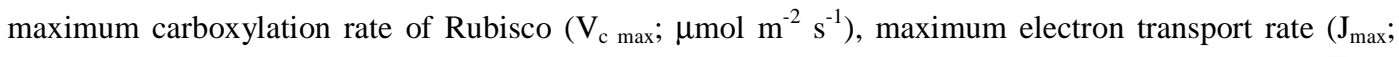
$\mu \mathrm{mol} \mathrm{m} \mathrm{m}^{-2}$ ) and triose phosphate utilisation rate (TPU; $\mu \mathrm{mol} \mathrm{m} \mathrm{m}^{-2} \mathrm{~s}^{-1}$ ) in tomato cultivars Leader and RAF. The $\mathrm{L}_{\mathrm{s}}, \mathrm{L}_{\mathrm{m}}, \mathrm{g}_{\mathrm{m}}, \mathrm{V}_{\mathrm{c} \max }, \mathrm{J}_{\max }$ and TPU parameters were estimated after 8 days of salt stress from 5 independent curves for each treatment and cultivar. $\mathrm{g}_{\mathrm{s}}$ is the mean of 12 different determinations.

\begin{tabular}{lllcccccc}
\hline & & $\mathrm{L}_{\mathrm{s}}$ & $\mathrm{L}_{\mathrm{m}}$ & $\mathrm{g}_{\mathrm{s}}$ & $\mathrm{g}_{\mathrm{m}}$ & $\mathrm{V}_{\mathrm{c} \max }$ & $\mathrm{J}_{\max }$ & $\mathrm{TPU}$ \\
\hline Leader & Control & 29 & $0 \mathrm{a}$ & $0.51 \mathrm{a}$ & $0.12 \mathrm{a}$ & $120 \mathrm{a}$ & $112 \mathrm{a}$ & 4.8 \\
& $\mathrm{NaCl}$ & $26 \mathrm{~ns}$ & $36 \mathrm{~b}$ & $0.27 \mathrm{~b}$ & $0.09 \mathrm{~b}$ & $55 \mathrm{~b}$ & $72 \mathrm{~b}$ & $4.5 \mathrm{~ns}$ \\
$\mathrm{RAF}$ & $\mathrm{Control}$ & 33 & $0 \mathrm{a}$ & $0.41 \mathrm{a}$ & $0.27 \mathrm{a}$ & $127 \mathrm{a}$ & 105 & $5.8 \mathrm{a}$ \\
& $\mathrm{NaCl}$ & $32 \mathrm{~ns}$ & $17 \mathrm{~b}$ & $0.24 \mathrm{~b}$ & $0.16 \mathrm{~b}$ & $96 \mathrm{~b}$ & $103 \mathrm{~ns}$ & $3.5 \mathrm{~b}$ \\
& & & & & & & &
\end{tabular}

Within each cultivar, different letters indicate significant differences $(P<0.05)$; ns: non-significant. 
Table 3.

Effect (\% control) of different salt concentrations and compositions on shoot, root and leaf dry weight and number of leaves. Values are presented as the percentages of controls. Each value is the mean of 12 different plants.

\begin{tabular}{|c|c|c|c|c|c|c|c|c|c|c|c|c|c|}
\hline & & Daniela & & & & Leader & & & $\gamma$ & RAF & & & \\
\hline \multirow[t]{2}{*}{ Salt } & & Shoot & Root & Leaf & $\mathrm{N}^{\mathrm{o}}$ & Shoot & Root & Leaf & $\mathrm{N}^{\mathrm{o}}$ & Shoot & Root & Leaf & $\mathrm{N}^{\mathrm{o}}$ \\
\hline & & DW & DW & DW & leaves & DW & DW & DW & leaves & DW & DW & DW & leaves \\
\hline \multirow[t]{3}{*}{$\mathrm{NaCl}$} & $25 \mathrm{mM}$ & $65 \mathrm{a}$ & $47 \mathrm{a}, \mathrm{C}$ & $64 \mathrm{a}$ & $94 \mathrm{a}$ & $78 \mathrm{a}$ & $79 \mathrm{a}, \mathrm{A}$ & $77 \mathrm{a}$ & $75 a$ & $83 a$ & $63 \mathrm{a}, \mathrm{B}$ & $80 \mathrm{a}$ & $92 \mathrm{a}$ \\
\hline & $50 \mathrm{mM}$ & $56 \mathrm{a}, \mathrm{B}$ & $44 \mathrm{a}, \mathrm{B}$ & $60 \mathrm{a}$ & $88 \mathrm{a}$ & $45 \mathrm{~b}, \mathrm{~B}$ & $50 \mathrm{~b}, \mathrm{~B}$ & $45 \mathrm{~b}$ & $69 \mathrm{a}$ & 82 a,A & 65 a,A & $77 \mathrm{a}$ & $84 \mathrm{ab}$ \\
\hline & $100 \mathrm{mM}$ & $51 \mathrm{a}, \mathrm{B}$ & $40 \mathrm{a}, \mathrm{C}$ & $50 \mathrm{a}$ & $80 \mathrm{a}$ & $48 \mathrm{~b}, \mathrm{~B}$ & $59 \mathrm{~b}, \mathrm{~A}$ & $47 \mathrm{~b}$ & $78 \mathrm{a}$ & $65 \mathrm{~b}, \mathrm{~A}$ & $53 \mathrm{~b}, \mathrm{AB}$ & $56 \mathrm{~b}$ & $75 \mathrm{~b}$ \\
\hline \multirow[t]{3}{*}{$\mathrm{Na}_{2} \mathrm{SO}_{4}$} & $25 \mathrm{mM}$ & $79 \mathrm{a}, \mathrm{A}$ & $71 \mathrm{a}$ & $81 \mathrm{a}$ & $90 \mathrm{a}$ & $55 \mathrm{a}, \mathrm{B}$ & $62 \mathrm{a}$ & $52 \mathrm{a}$ & $80 \mathrm{a}$ & $81 \mathrm{a}, \mathrm{A}$ & $71 \mathrm{a}$ & $75 \mathrm{a}$ & $91 \mathrm{a}$ \\
\hline & $50 \mathrm{mM}$ & $61 \mathrm{~b}, \mathrm{~A}$ & $54 \mathrm{~b}$ & $64 \mathrm{~b}$ & $88 \mathrm{a}$ & $37 \mathrm{~b}, \mathrm{~B}$ & $50 \mathrm{a}$ & $34 \mathrm{~b}$ & $63 \mathrm{~b}$ & $55 \mathrm{~b}, \mathrm{~A}$ & $40 \mathrm{~b}$ & $41 \mathrm{~b}$ & $56 \mathrm{~b}$ \\
\hline & $100 \mathrm{mM}$ & $30 \mathrm{c}, \mathrm{AB}$ & $20 \mathrm{c}$ & $29 \mathrm{c}$ & $63 \mathrm{~b}$ & $22 \mathrm{c}, \mathrm{B}$ & $23 \mathrm{~b}$ & $17 \mathrm{c}$ & $44 \mathrm{c}$ & $33 \mathrm{c}, \mathrm{A}$ & $26 \mathrm{c}$ & $17 \mathrm{c}$ & $35 \mathrm{c}$ \\
\hline \multirow[t]{3}{*}{$\mathrm{MgCl}_{2}$} & $25 \mathrm{mM}$ & $93 \mathrm{a}, \mathrm{A}$ & $64 \mathrm{a}, \mathrm{A}$ & $92 \mathrm{a}$ & $92 a$ & $75 \mathrm{a}, \mathrm{AB}$ & $59 \mathrm{a}, \mathrm{AB}$ & $75 \mathrm{a}$ & $76 a$ & $67 \mathrm{a}, \mathrm{B}$ & $45 \mathrm{a}, \mathrm{B}$ & $57 \mathrm{a}$ & $71 \mathrm{a}$ \\
\hline & $50 \mathrm{mM}$ & $71 \mathrm{~b}, \mathrm{~A}$ & 48 a,A & $66 \mathrm{~b}$ & $84 \mathrm{a}$ & $56 \mathrm{a}, \mathrm{B}$ & $44 \mathrm{~b}, \mathrm{AB}$ & $55 \mathrm{~b}$ & $74 \mathrm{a}$ & $55 \mathrm{a}, \mathrm{B}$ & $29 \mathrm{~b}, \mathrm{~B}$ & $44 \mathrm{a}$ & $49 \mathrm{~b}$ \\
\hline & $100 \mathrm{mM}$ & $20 \mathrm{c}, \mathrm{B}$ & 12 b,C & $14 \mathrm{c}$ & $29 \mathrm{~b}$ & $34 \mathrm{~b}, \mathrm{~A}$ & $33 \mathrm{~b}, \mathrm{~A}$ & $33 \mathrm{c}$ & $61 \mathrm{~b}$ & $31 \mathrm{~b}, \mathrm{~A}$ & $24 \mathrm{~b}, \mathrm{~B}$ & $12 \mathrm{~b}$ & $11 \mathrm{c}$ \\
\hline \multirow[t]{3}{*}{$\mathrm{MgSO}_{4}$} & $25 \mathrm{mM}$ & $79 a$ & 56 a,B & $78 \mathrm{a}$ & $85 \mathrm{a}$ & $90 \mathrm{a}$ & 80 a,A & $92 \mathrm{a}$ & $97 \mathrm{a}$ & $79 a$ & $64 \mathrm{a}, \mathrm{AB}$ & $74 \mathrm{a}$ & $77 \mathrm{a}$ \\
\hline & $50 \mathrm{mM}$ & $57 \mathrm{~b}$ & $31 \mathrm{~b}, \mathrm{~B}$ & $52 \mathrm{~b}$ & $75 a$ & $48 \mathrm{~b}$ & $46 \mathrm{~b}, \mathrm{~A}$ & $47 \mathrm{~b}$ & $69 \mathrm{~b}$ & $57 \mathrm{~b}$ & $33 \mathrm{~b}, \mathrm{~B}$ & $47 \mathrm{~b}$ & $60 \mathrm{~b}$ \\
\hline & $100 \mathrm{mM}$ & 49 b,A & $30 \mathrm{~b}, \mathrm{~A}$ & $49 \mathrm{~b}$ & $76 \mathrm{a}$ & $32 \mathrm{~b}, \mathrm{~B}$ & $25 \mathrm{c}, \mathrm{AB}$ & $30 \mathrm{~b}$ & $48 \mathrm{c}$ & $36 \mathrm{c}, \mathrm{B}$ & $21 \mathrm{c}, \mathrm{B}$ & $19 \mathrm{c}$ & $32 \mathrm{c}$ \\
\hline
\end{tabular}

Within each salt and cultivar, and for each biomass parameter, different lowercase letters indicate significant differences among concentrations $(P<0.05)$. Significant differences $(P<0.05)$ among cultivars for each salt type and concentration are indicated by uppercase letters. 
Table 4

Relationship between the photosynthetic rate and biomass parameters (number of leaves; shoot length; stem, root, leaf and shoot dry weight (DW); and leaf area).

\begin{tabular}{|c|c|c|c|c|c|c|c|}
\hline & No. leaves & Shoot length & Stem DW & Root DW & Leaf DW & Shoot DW & Leaf area \\
\hline Daniela & $0.79 * *$ & $0.67 *$ & $0.52 \mathrm{~ns}$ & $0.81 * *$ & $0.66 *$ & 0.6 & $0.83 * *$ \\
\hline Leader & $0.91 * *$ & $0.88 * *$ & $0.86 * *$ & $0.88 * *$ & $0.88 * *$ & $0.88 * *$ & $0.93 * *$ \\
\hline RAF & $0.91 * *$ & $0.93 * *$ & $0.92 * *$ & $0.92 * *$ & $0.93 * *$ & $0.93 * *$ & $0.90 * *$ \\
\hline
\end{tabular}

** $\mathrm{P}<0.01 ; * \mathrm{P}<0.05 ;$ ns: non-significant 
Table 5

The effect of different salts on the relationship between shoot and root dry weight among the tomato cultivars Daniela, Leader and RAF. Each value is the mean of 12 different plants.

\begin{tabular}{llrlrlll}
\hline & & Daniela & Leader & RAF & \\
\hline $\mathrm{NaCl}$ & $25 \mathrm{mM}$ & 1.40 & $\mathrm{a}$ & 1.11 & $\mathrm{a}$ & 1.35 & $\mathrm{a}$ \\
& $50 \mathrm{mM}$ & 1.32 & $\mathrm{a}$ & 1.07 & $\mathrm{a}$ & 1.26 & $\mathrm{a}$ \\
& $100 \mathrm{mM}$ & 1.40 & $\mathrm{a}$ & 0.87 & $\mathrm{~b}$ & 1.25 & $\mathrm{a}$ \\
\hline $\mathrm{Na}_{2} \mathrm{SO}_{4}$ & $25 \mathrm{mM}$ & 1.15 & $\mathrm{a}$ & 0.92 & $\mathrm{~b}$ & 1.16 & $\mathrm{a}$ \\
& $50 \mathrm{mM}$ & 1.33 & $\mathrm{a}$ & 0.67 & $\mathrm{~b}$ & 1.46 & $\mathrm{a}$ \\
& $100 \mathrm{mM}$ & 1.61 & $\mathrm{a}$ & 0.89 & $\mathrm{~b}$ & 1.16 & $\mathrm{~b}$ \\
\hline $\mathrm{MgCl}_{2}$ & $25 \mathrm{mM}$ & 1.49 & $\mathrm{ab}$ & 1.25 & $\mathrm{~b}$ & 1.55 & $\mathrm{a}$ \\
& $50 \mathrm{mM}$ & 1.76 & $\mathrm{a}$ & 1.30 & $\mathrm{~b}$ & 1.88 & $\mathrm{a}$ \\
& $100 \mathrm{mM}$ & 1.77 & $\mathrm{a}$ & 1.08 & $\mathrm{~b}$ & 0.73 & $\mathrm{~b}$ \\
\hline $\mathrm{MgSO}_{4}$ & $25 \mathrm{mM}$ & 1.78 & $\mathrm{a}$ & 1.11 & $\mathrm{~b}$ & 1.26 & $\mathrm{ab}$ \\
& $50 \mathrm{mM}$ & 1.94 & $\mathrm{a}$ & 1.04 & $\mathrm{~b}$ & 1.75 & $\mathrm{a}$ \\
& $100 \mathrm{mM}$ & 1.60 & $\mathrm{a}$ & 1.37 & $\mathrm{a}$ & 1.72 & $\mathrm{a}$ \\
\hline
\end{tabular}

Within each salt and concentration, different letters indicate significant differences $(P<0.05)$. 
Table 6

Effect of type of salt and concentration in the nutrient solution on the calcium, potassium, magnesium, sodium, chloride, phosphate and sulphate content in the leaves of RAF and Daniela plants. Each value ( $\mathrm{mmol} \mathrm{g}^{-1}$ of leaf DW) is the mean of three determinations from three different extracts. Four different plants were pooled to generate each extract.

\begin{tabular}{|c|c|c|c|c|c|c|c|c|c|c|c|c|c|c|c|}
\hline \multirow{2}{*}{ RAF } & \multirow[t]{2}{*}{$\mathrm{mM}$} & \multicolumn{2}{|c|}{$\mathrm{Ca}^{2+}$} & \multicolumn{2}{|c|}{$\mathrm{K}^{+}$} & \multicolumn{2}{|c|}{$\mathrm{Mg}^{2+}$} & \multicolumn{2}{|c|}{$\mathrm{Na}^{+}$} & \multicolumn{2}{|c|}{$\mathrm{Cl}^{-}$} & \multicolumn{2}{|c|}{$\mathrm{PO}_{4}{ }^{3-}$} & \multicolumn{2}{|c|}{$\mathrm{SO}_{4}^{2-}$} \\
\hline & & & & & & & & & & & & & & & \\
\hline \multirow[t]{4}{*}{$\mathrm{NaCl}$} & 0 & 0.87 & $\mathrm{a}$ & 0.72 & $\mathrm{a}$ & 0.33 & $\mathrm{a}$ & 0.20 & $\mathrm{~d}$ & 0.49 & $\mathrm{~d}$ & 0.19 & & 0.37 & $\mathrm{a}$ \\
\hline & 25 & 0.62 & $\mathrm{bc}$ & 0.49 & $\mathrm{bc}$ & 0.29 & $a b$ & 0.68 & c & 1.14 & $\mathrm{c}$ & 0.16 & & 0.30 & $a b$ \\
\hline & 50 & 0.67 & $a b$ & 0.54 & $\mathrm{~b}$ & 0.25 & $\mathrm{bc}$ & 1.17 & $\mathrm{~b}$ & 1.48 & $\mathrm{~b}$ & 0.19 & & 0.31 & $a b$ \\
\hline & 100 & 0.45 & $\mathrm{c}$ & 0.36 & $\mathrm{c}$ & 0.21 & $\mathrm{c}$ & 1.58 & $\mathrm{a}$ & 2.22 & $\mathrm{a}$ & 0.16 & ns & 0.25 & $\mathrm{~b}$ \\
\hline \multirow[t]{4}{*}{$\mathrm{Na}_{2} \mathrm{SO}_{4}$} & 0 & 0.87 & $\mathrm{a}$ & 0.72 & $\bar{a}$ & 0.33 & $\mathrm{a}$ & 0.20 & $\mathrm{c}$ & 0.49 & & 0.19 & $\mathrm{a}$ & 0.37 & $d$ \\
\hline & 25 & 0.42 & $\mathrm{~b}$ & 0.36 & $\mathrm{~b}$ & 0.21 & b & 0.99 & b & 0.52 & & 0.16 & b & 1.15 & $\mathrm{c}$ \\
\hline & 50 & 0.47 & $\mathrm{~b}$ & 0.28 & $\mathrm{~b}$ & 0.25 & b & 1.26 & b & 0.49 & & 0.13 & $\mathrm{bc}$ & 1.65 & $\mathrm{~b}$ \\
\hline & 100 & 0.42 & $\mathrm{~b}$ & 0.43 & $\mathrm{~b}$ & 0.25 & $\mathrm{~b}$ & 2.04 & $\mathrm{a}$ & 0.44 & ns & 0.10 & $\mathrm{c}$ & 3.48 & $\mathrm{a}$ \\
\hline \multirow[t]{4}{*}{$\mathrm{MgCl}_{2}$} & 0 & 0.87 & $\mathrm{a}$ & 0.72 & $\mathrm{a}$ & 0.33 & $\mathrm{c}$ & 0.20 & & 0.49 & $\mathrm{~d}$ & 0.19 & $\mathrm{a}$ & 0.37 & $\mathrm{a}$ \\
\hline & 25 & 0.27 & $\mathrm{~b}$ & 0.23 & $\mathrm{~b}$ & 0.82 & $\mathrm{~b}$ & 0.14 & & 1.61 & c & 0.09 & $\mathrm{~b}$ & 0.26 & $\mathrm{~b}$ \\
\hline & 50 & 0.42 & $\mathrm{~b}$ & 0.26 & $\mathrm{~b}$ & 1.44 & $\mathrm{a}$ & 0.17 & & 2.64 & $\mathrm{~b}$ & 0.10 & $\mathrm{~b}$ & 0.22 & bc \\
\hline & 100 & 0.25 & $\mathrm{~b}$ & 0.31 & $\mathrm{~b}$ & 1.56 & $\mathrm{a}$ & 0.12 & ns & 3.85 & $\mathrm{a}$ & 0.06 & $\mathrm{~b}$ & 0.16 & $\mathrm{c}$ \\
\hline \multirow[t]{4}{*}{$\mathrm{MgSO}_{4}$} & 0 & 0.87 & $\mathrm{a}$ & 0.72 & $\mathrm{a}$ & 0.33 & $\mathrm{~b}$ & 0.20 & $\mathrm{a}$ & 0.49 & & 0.19 & $\mathrm{a}$ & 0.37 & d \\
\hline & 25 & 0.40 & $\mathrm{~b}$ & 0.38 & $\mathrm{~b}$ & 0.82 & $a b$ & 0.23 & $\mathrm{a}$ & 0.63 & & 0.16 & $\mathrm{~b}$ & 0.88 & $\mathrm{c}$ \\
\hline & 50 & 0.42 & $\mathrm{~b}$ & 0.26 & $\mathrm{c}$ & 0.95 & $\mathrm{a}$ & 0.20 & $\mathrm{a}$ & 0.47 & & 0.10 & $\mathrm{c}$ & 1.39 & $\mathrm{~b}$ \\
\hline & 100 & 0.37 & $\mathrm{~b}$ & 0.23 & $\mathrm{c}$ & 1.36 & $\mathrm{a}$ & 0.10 & $\mathrm{~b}$ & 0.44 & ns & 0.10 & $\mathrm{c}$ & 2.96 & $\mathrm{a}$ \\
\hline \multicolumn{16}{|l|}{ Daniela } \\
\hline \multirow[t]{4}{*}{$\mathrm{NaCl}$} & 0 & 0.57 & & 0.60 & & 17 & & 0.07 & $\mathrm{~b}$ & 0.26 & $\mathrm{c}$ & 0.15 & & 0.29 & $\mathrm{a}$ \\
\hline & 25 & 0.60 & & 0.70 & & 0.17 & & 0.25 & $a b$ & 1.06 & $\mathrm{~b}$ & 0.17 & & 0.23 & $\mathrm{~b}$ \\
\hline & 50 & 0.60 & & 0.79 & & 0.17 & & 0.37 & $a b$ & 1.30 & $\mathrm{a}$ & 0.20 & & 0.21 & bc \\
\hline & 100 & 0.50 & ns & 0.50 & ns & 0.17 & ns & 0.65 & b & 1.29 & $\mathrm{a}$ & 0.17 & ns & 0.16 & $\mathrm{c}$ \\
\hline \multirow[t]{4}{*}{$\mathrm{Na}_{2} \mathrm{SO}_{4}$} & 0 & 0.57 & & 0.60 & $\mathrm{a}$ & 0.17 & & 0.07 & $\mathrm{c}$ & 0.26 & $\mathrm{~b}$ & 0.15 & & 0.29 & $\mathrm{c}$ \\
\hline & 25 & 0.50 & & 0.55 & $a b$ & 0.15 & & 0.37 & $\mathrm{~b}$ & 0.55 & $\mathrm{a}$ & 0.17 & & 0.34 & bc \\
\hline & 50 & 0.47 & & 0.42 & $\mathrm{~b}$ & 0.15 & & 0.45 & $\mathrm{~b}$ & 0.57 & $\mathrm{a}$ & 0.17 & & 0.46 & $\mathrm{~b}$ \\
\hline & 100 & 0.45 & $\mathrm{~ns}$ & 0.42 & $\mathrm{~b}$ & 0.15 & ns & 0.60 & $\mathrm{a}$ & 0.68 & $\mathrm{a}$ & 0.15 & ns & 0.86 & $\mathrm{a}$ \\
\hline \multirow[t]{4}{*}{$\mathrm{MgCl}_{2}$} & 0 & 0.57 & $a$ & 0.60 & $a$ & 0.17 & $\mathrm{c}$ & 0.07 & $a$ & 0.26 & $\mathrm{c}$ & 0.15 & & 0.29 & $a$ \\
\hline & 25 & 0.37 & $\mathrm{~b}$ & 0.55 & $\mathrm{a}$ & 0.50 & $\mathrm{~b}$ & 0.05 & $\mathrm{~b}$ & 1.22 & $\mathrm{~b}$ & 0.15 & & 0.15 & b \\
\hline & 50 & 0.40 & $a b$ & 0.47 & $a b$ & 0.65 & $\mathrm{~b}$ & 0.05 & $\mathrm{~b}$ & 1.38 & $\mathrm{~b}$ & 0.15 & & 0.14 & b \\
\hline & 100 & 0.47 & $a b$ & 0.35 & $\mathrm{~b}$ & 1.17 & $\mathrm{a}$ & 0.05 & $\mathrm{~b}$ & 3.44 & $\mathrm{a}$ & 0.10 & ns & 0.15 & b \\
\hline \multirow[t]{4}{*}{$\mathrm{MgSO}_{4}$} & 0 & 0.57 & $\mathrm{a}$ & 0.60 & $a b$ & 0.17 & $\mathrm{~b}$ & 0.07 & & 0.26 & & 0.15 & & 0.29 & $\mathrm{c}$ \\
\hline & 25 & 0.35 & $\mathrm{~b}$ & 0.75 & $\mathrm{a}$ & 0.50 & $\mathrm{a}$ & 0.05 & & 0.31 & & 0.17 & & 0.52 & b \\
\hline & 50 & 0.42 & $a b$ & 0.70 & $\mathrm{a}$ & 0.55 & $\mathrm{a}$ & 0.05 & & 0.26 & & 0.20 & & 0.60 & $\mathrm{~b}$ \\
\hline & 100 & 0.35 & $\mathrm{~b}$ & 0.35 & $\mathrm{~b}$ & 0.42 & $\mathrm{a}$ & 0.07 & ns & 0.24 & ns & 0.15 & ns & 1.01 & $\mathrm{a}$ \\
\hline
\end{tabular}

For each cultivar, within each element and salt, different letters indicate significant differences $(\mathrm{P}<0.05) . \mathrm{ns}=$ non-significant 


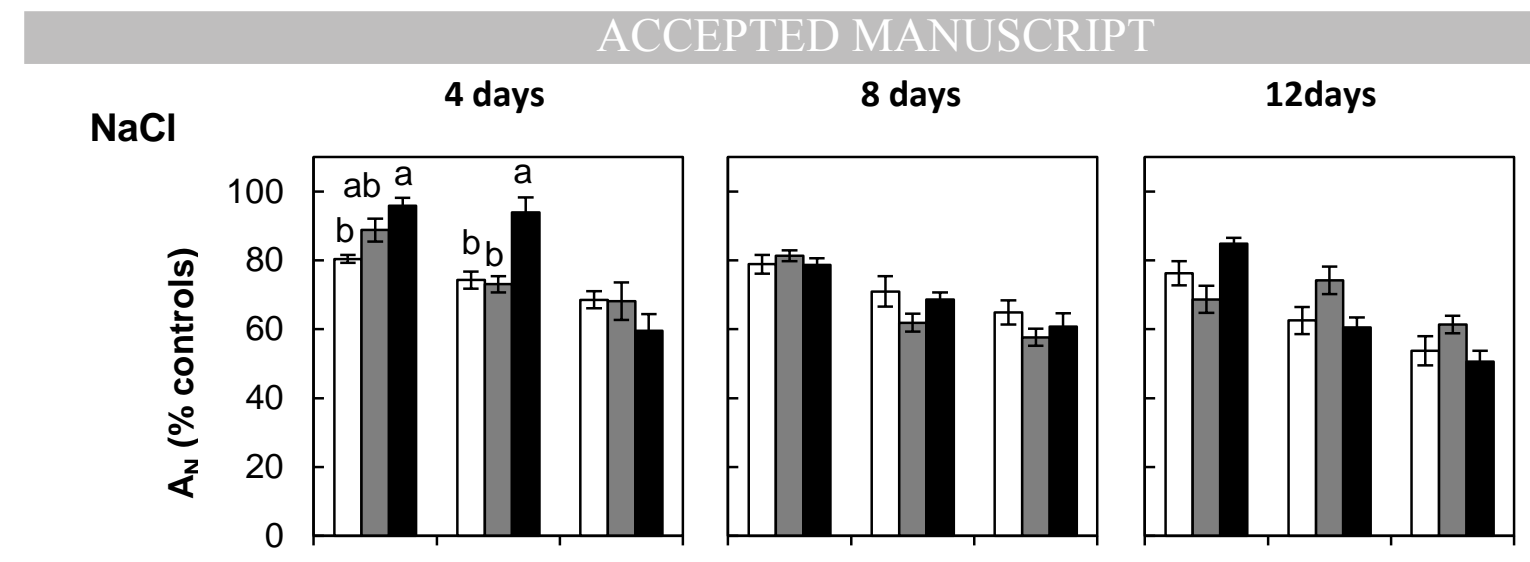

$\mathrm{Na}_{2} \mathrm{SO}_{4}$
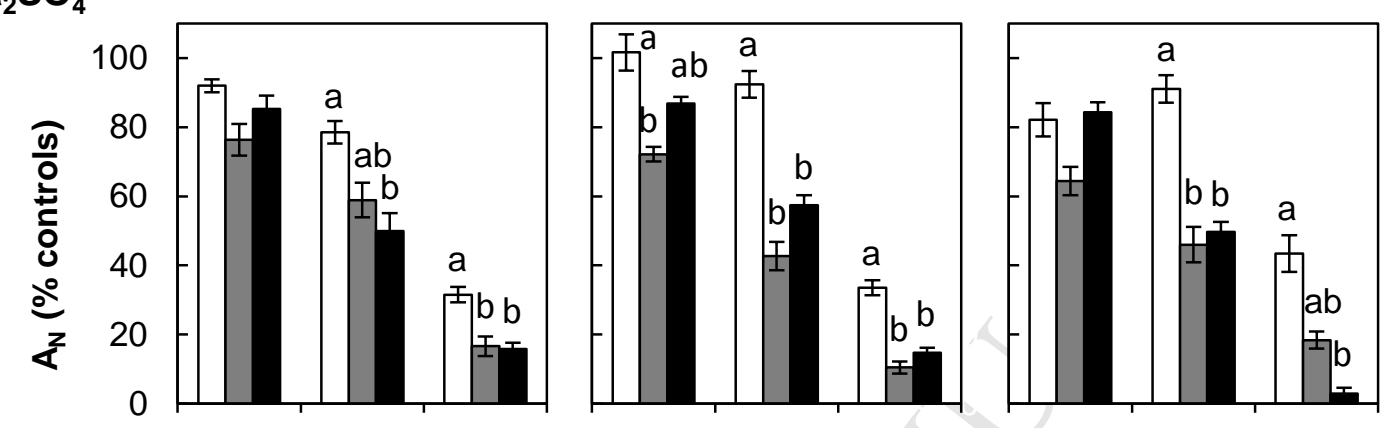

$\mathrm{MgCl}_{2}$
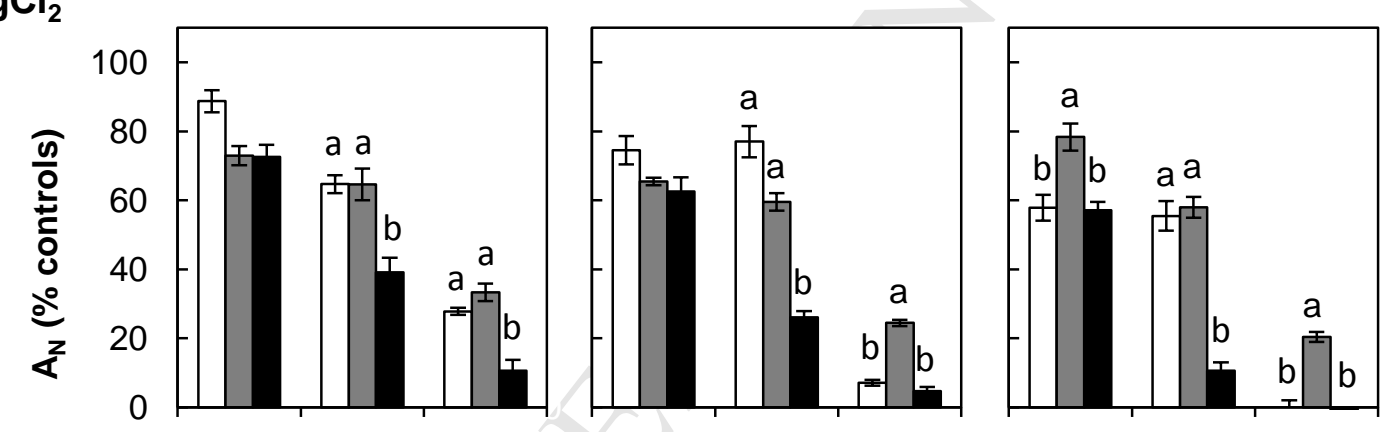

$\mathrm{MgSO}_{4}$
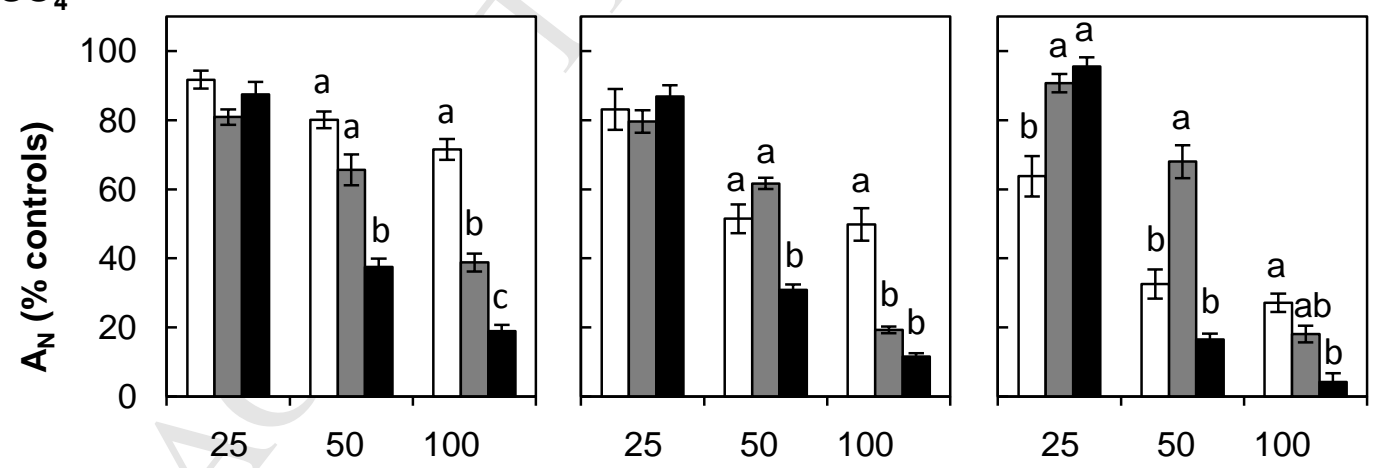

Salt concentration (mM) 

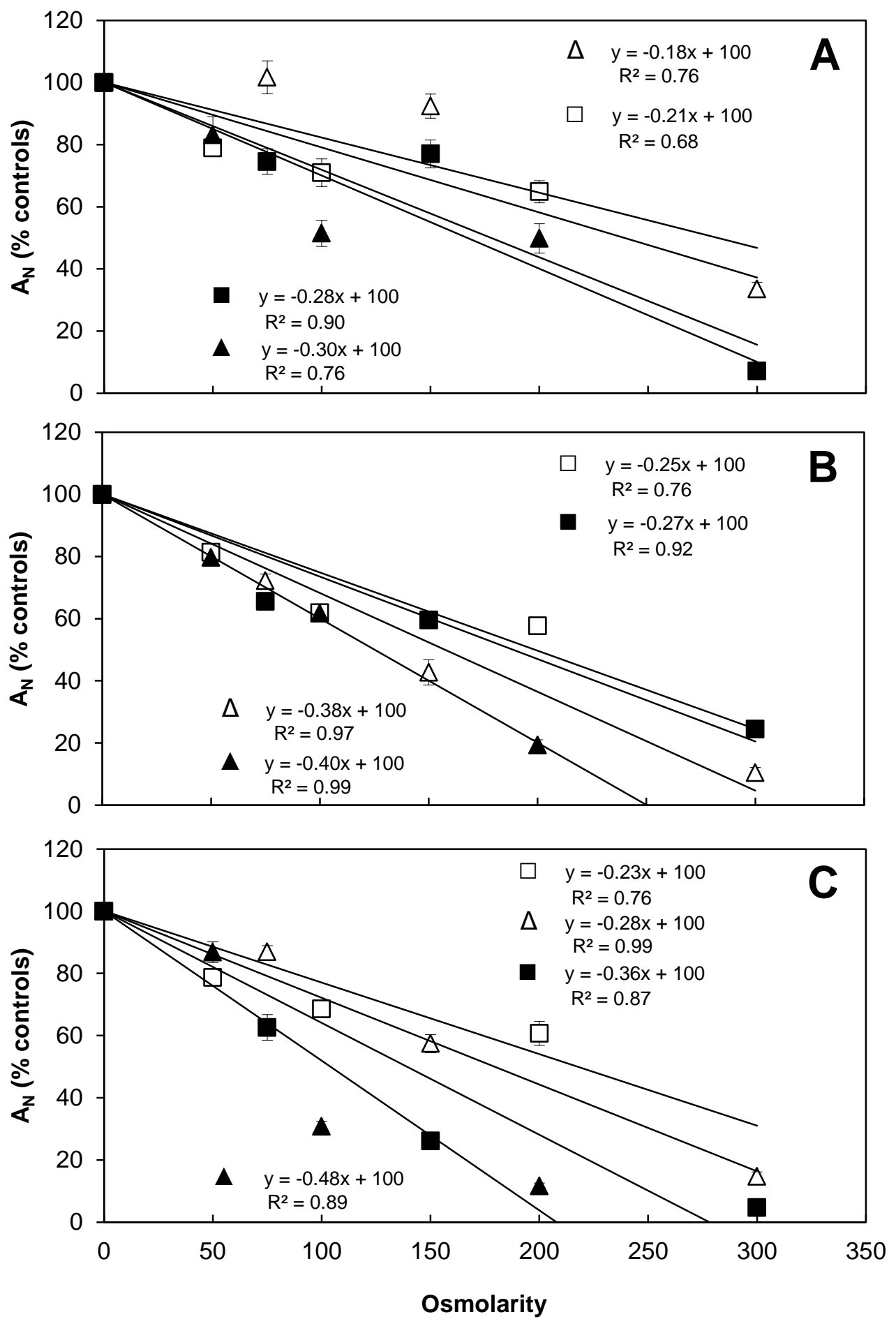

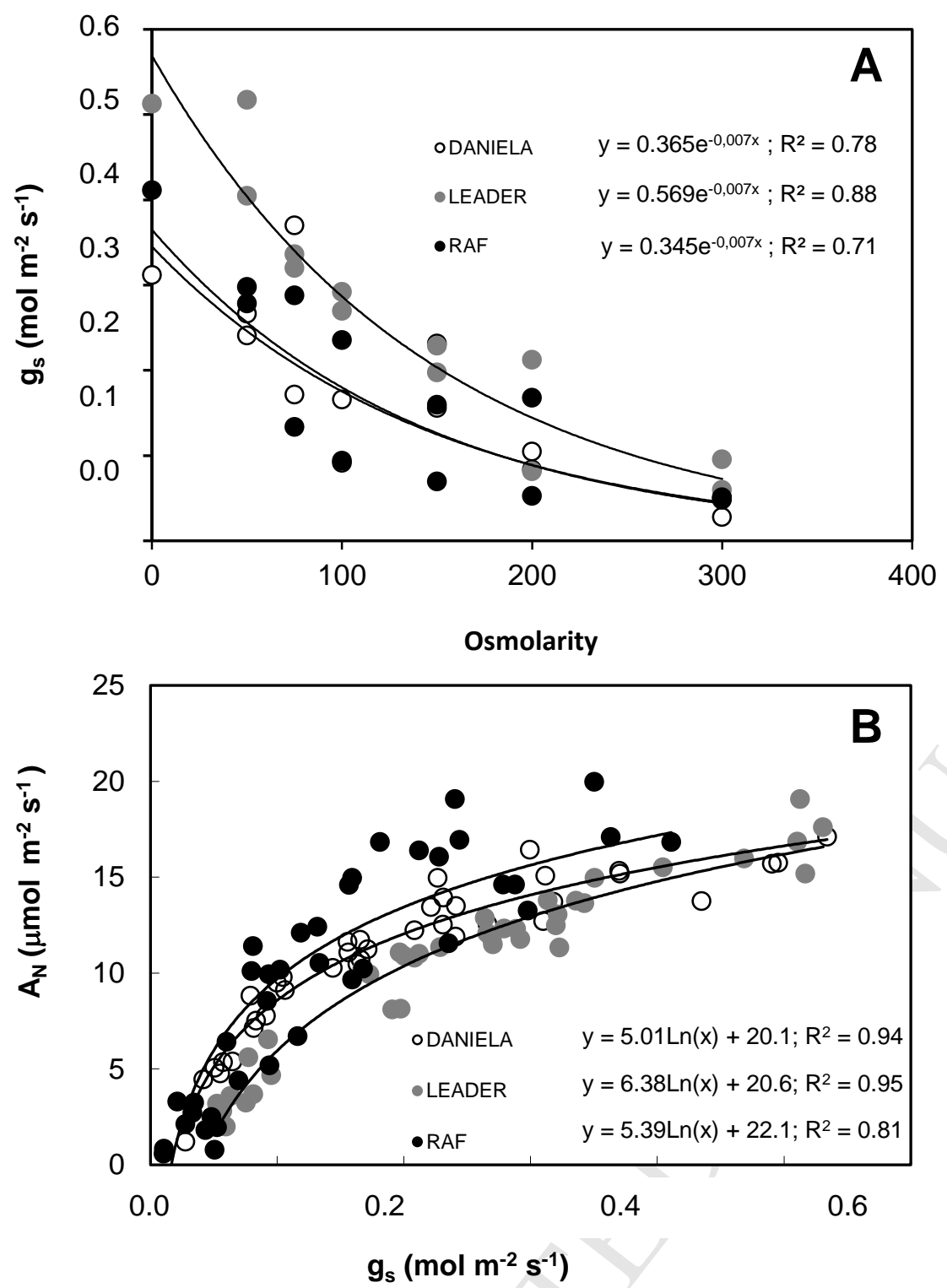

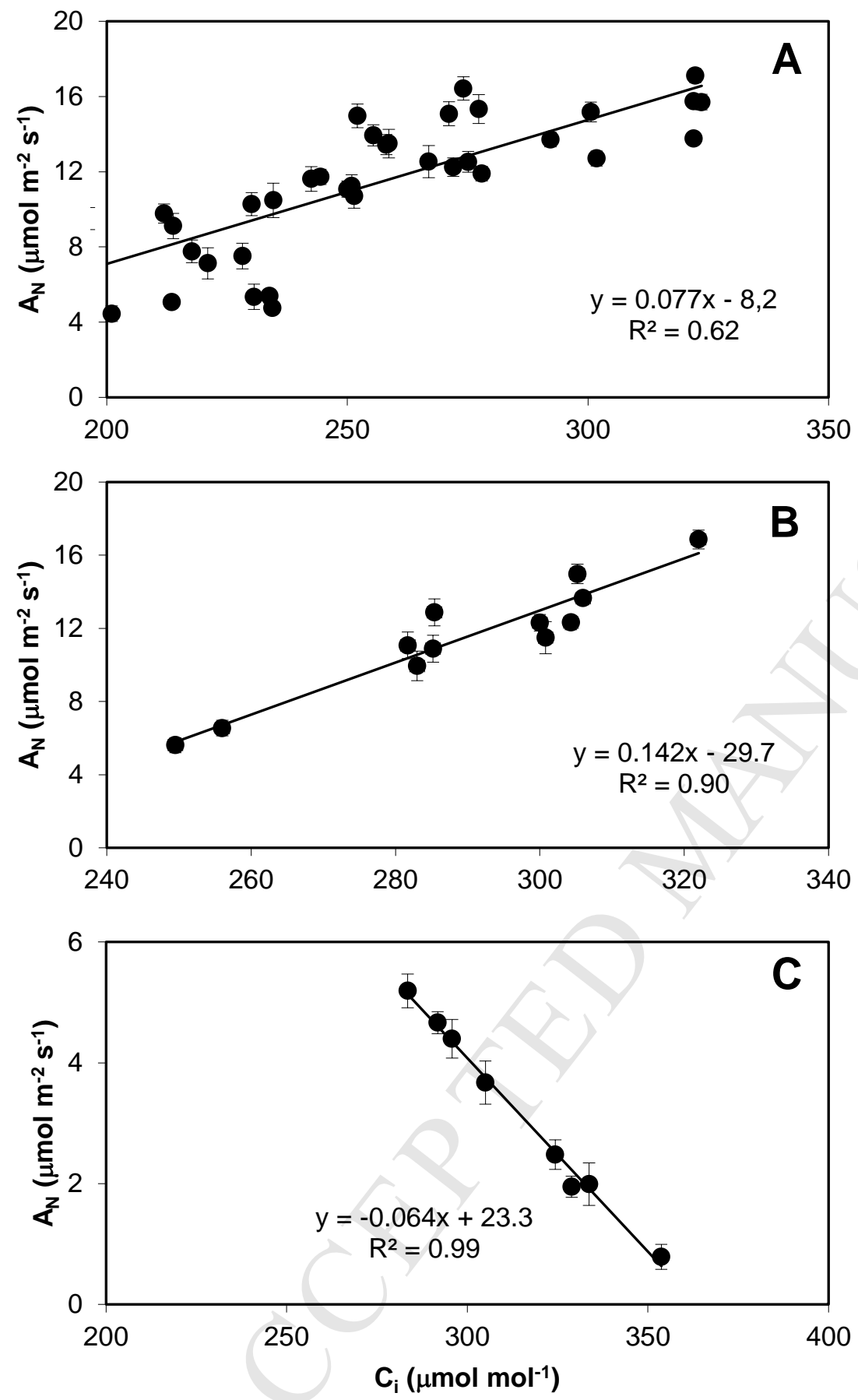

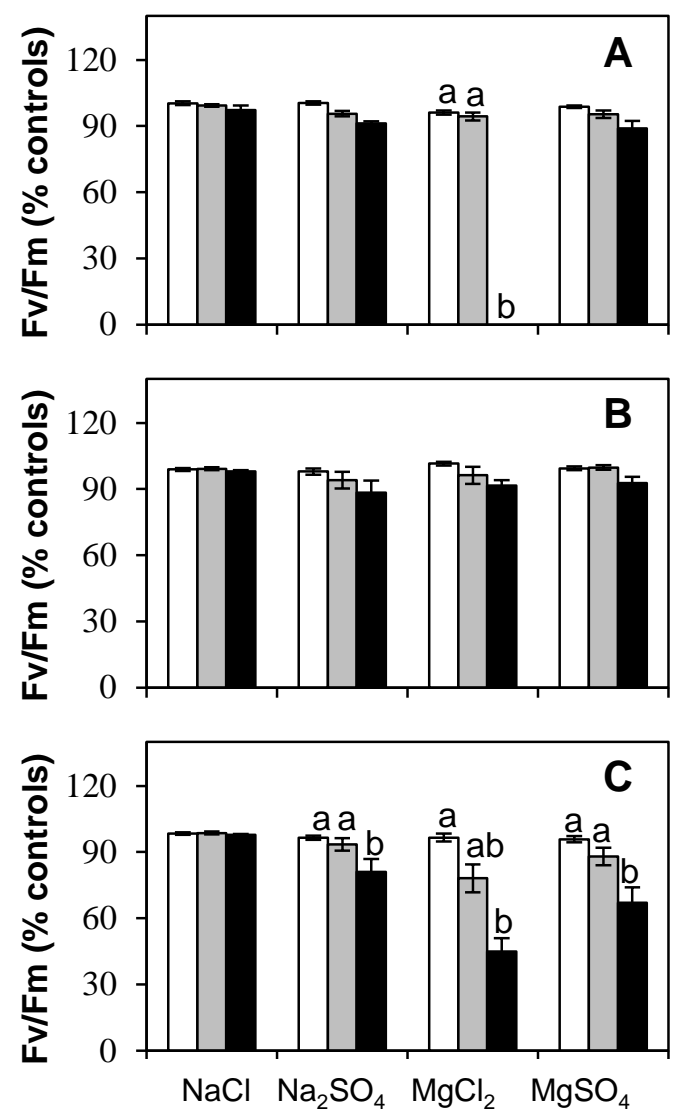